State of Alagka

Department of Netural Resources

IVISION OF MTNES AND MJNERALS.
PROPERTY OF

LIBRARY

STATE OF ALASKA DIVISION OF

GeOLOGICAL SURVEY
P. 0. Box 1391

Juneer, Alaska, $i$

MTNES AND PETROTEUM BUIFIN

october 1963

Yol. XI

No., 10

MINIIG ACTIVIPIISS

Nortbwestern

Both Newmont and USSR8M have completed their exploratory work for this wason on the beryllium claims in the Iost River area. The Tweets are mining at Taylor with aredge and a eluscing operation. Martinson Brotbers ere dredging above the North Fork of the

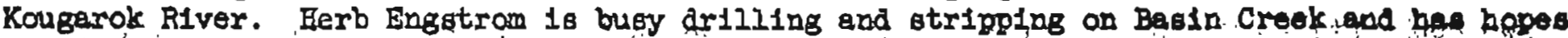
of getting his dredge golng. Van Chambers 18. mlalng on El Dorado Creek.

Central

The vitro kinorali corp, has a mall crew working on equipant and bididtag camp Fecllities. The Usibelil Mine is loeding about 1500 tons of coal par day and will 1ncirease-. thls eubstentlally a winter approaches. W1ley Rob1nson, Coel Mine Inspector, roporta that the Delts Coal Company his a good bed of coal opened up.

Southwestarn

The Matanuaka Coel Campany has rashed and stockplled several thousand tans of cpal

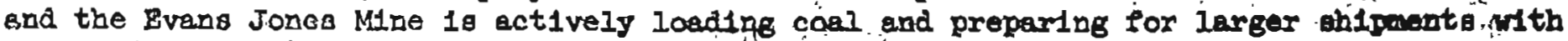
the coming of wipter.

\title{
COAL TENB
}

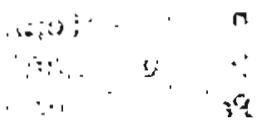

Safety Law Change Proposed.

Secretary of the Interlor Udall has subitted to Congress proposed leglolation to strengthen cosl mine safety laws. Tie proposal would tighten Pederal safoty rulen and also would extend these rules to some 8,000 mall mines not now covered. One of the mogt farreaching espects of the proposed legislation is to include under mandatory Federai sarety provistons the thousands of smalif conl minos, those ufth fewer then 15 underground employeen, which represent 70 per cent of the coel nutnes in the Untted states. These are ciaseod as Titie I mines and are presently exemt frox the laws covering the larger mines or Title II uines. Another proposal woulà elicinate tise Grendegtber clous in which tranglt1on

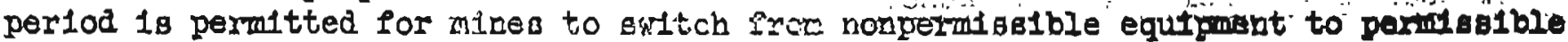
equipment. Another proposal, would require eeparate vent1lation for esch workdng bect1on of a mine, regardess of $1 \pm s$ etze:

Gasoline at 13.6 per Galton fron Coal.

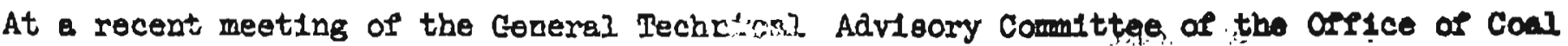
Fesearch a proposel of Consolidation Coal Company, Inc. Por the conversion of coal to gesoline wa diecuesed. Mr. J. A. Phtaney, Director of Research of Consolidation Coal Co., gave a comprehengtive description of the technical and econcmic aspects of the prooess including flowicheets, plant energy belances, products and an economle comparison between a coal repinery uaing the company' process and a new oll refinery. 
The company has a process for making gasoline out of coal that has the potentlal of being competitive. The compeny and its assoclates have spent twelve years and $\$ 91 / 2$. mili1on on laboratory research and on developing the process and equiphent. The linvest1gations have proceeded to the point where a pilot plant is to be the next otep. The company Intends to go ahead with 1ta research but with goverament assiatance the process would be bestened by several years. The econonies are such that the flret condserclal plant would uge about 10,000 tons of conl a day and produce 32,000 barrela a day of gasoline. The gesoline would be produced for 13.64 a gallon but with process and flowsheet improvements made during the course of the project it is hoped that this cost could be reduced. The cost of the project $1 \mathrm{~s}$ estimated to be $\$ 10$ million: . The members of the committee expressed approval of proceeding with the project up to the point of completion of bench acale work. At this time they will revlew the resulta and decide whether to go ahead with the pliot plapt.

\section{$\therefore \quad$ OIl NGWS}

Two epplications for permit to drill were approved this month as follows:

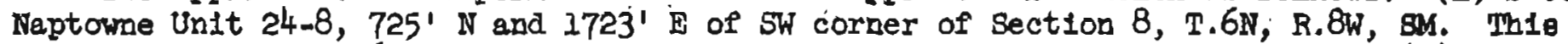
location lies about 6 miles southeast of the Soldotna Creek Unit production. (2) Bhell 011 Company, North Cook Inlet State \#1, 1320' N and 1320' $B$ of SW corner of Sect1on 29, 12N., 9W., SM. Th1s Iocation 1108 in Cook Inlet about 2 miles northeast of Pan American's Cook Inlet \#I wich 18 presently buraitig but which is expected to be plugged off within the coming week.

Dr12ling Aotivity:

Operator

Colorado O11 \& Gea Corp.

Ruchfield

Pan American

Pan Amerlcan

Pan American

Pan Amer1can

SoCal

Gulf: O11 Corp.

Superitor

\section{Completian:}

Shell 011 Company

Union 011 Company
Well Number

Gub1k Un1t \#I

Wide Bay Unit

Cook Inlet \#1

Midale Ground shosl \#2

Cook Inlet \#IA (Reller Well)

Tyonek State \#2

B.C.U. 23-3

Sendy River Federal \#1

Happy Vailey Un1t 31-22

\section{Status 9/28/63}

Testing

Drilling

Durn1ng

Drilling

Drilling

Drilling

Drilling

Drilling

Drilling
Midale Ground shoel \#l Ka1k Arm Stete \#I
Suspendod o1l. well Plugged \& ebandoned.

Product Lon, Swanson RIver Fleld, Bemlock Zone:

Producing Wells

53

Auguat, 1963

Cumulat1ve to September 1, 1963

Production, Kena1 Ges Fleld:

August, 1963

Cumilat 1 vo to september 1, 1963
01l-Earrele

896,308

$24,441,743$
Ges (MCD)

238,587

$5,025,754$
3

107.,963:

$3,635,779$ 
Production, Sterling Gas Field:

Produclng We11s

O11-Bargels Car (MCF)

ugrust; ' 1963

1

3,964

Cumulative to september 1, 1963

55,109

Production, Swanson R1ver Ges Fleld, Kenal Zone:

Auguat, 1963

Cumulative to september $1,1963^{\circ}$

6

Correction lest month: * from 375,116 to $539 ; 363$ and;

$$
\text { ** from } 2,533,212 \text { to } 2,697,457
$$

Ges Infectlon; Swanson River Flel'a, Hemlock Zone:

Augrat, 1963

Cumulative to September 1, 1963

3

$500,566 *$

3,$198 ; 023 * *$

Shell O1L Company Announces O1I Discovery at Midale Ground Shoal:

For the last 5 years the ofl and ges industry in Alaske bas been derfing most of the encouragement for 1t: ever lacreasing exploration effort from the discovary of the glant Swanson River Fleld.

This month the long endurlug effort was tanglibly fewarded at shell oll Compan's MAdde Ground Shoal \#2 when "a 48 -hour potentiel tegt flowed oll at the rate of at least 700 berrels of oll per day thirough e 5/8". top hole choke from an interval 7, 480 to 1,177 feet". :Th1s wildcat oll alscoverit was operated by Shell ofl Company with standard ill Company of Celffornio and the Richfield Oll Campany as partners. Anyone aboard the Cuss II arliling vessel whlch arilied thls well, can attest to the vallalty of the statement that Cook Inlet offahore drilling presents the most difflcult problems of offohore arilling in the world beceuse of 30 foot tides, 8 knot currents changing direction 4 times a day, silty water, floeting debrls and bigh winds. It lies in 125' of water 3 miles oouth of Pan American Petroleum's Middle Ground Shoal. \#l which discovered ges at ohallow depths last year and was plugged when it became imposibible to control the well.

Rather than risk the danger of mechanlcal damage to oubmerged well head equipment and posalble escepe of crude oll into Cook Inlet, Shell was permitted to eet a drillable plus on top of the pay and place several cement plugs in the bole. The woll will be $2 \mathrm{eft}$ in this state until productive capac1ty from additional wells will warrant large beale product1on and storage fecilities.

Arctic Slope Development Contract Approved:

Shell 011 Company and Standard Oll Company of Californie will be operators of the Echookin Ret Development Contract which lies considerably east of the three bther approved development contracts on the Arctic slope." The contract contalus 659,975 acres and calle for the drilling of the flrst exploratory well prior to July. 1, 1966, following inltial exploratory work.

\section{TWELFIH COMPEIITIVE OI AND GAS LEASE SALE}

The DIv1sion of Lands anoibce that it will kold its Twe fth Competitive o1l and Gas ease Sele Wednesday December 2I, 1963. They are anxtous to consider leasing those areas 
which are of special interest to the industry. Among avaliable areas of interest are unleased Mental Health, University and School lands, and any of the Alaska coatal areas within the three mile limit from the coast line. Nominations to be considered for the December sale will be accepted from the date of this notice unt1l the close of bubineis at 3:00 PM, September 27. The areas nominated will be announced by October 4.

\section{NEW GOLD BILI}

The :B1ll (S. 2l25) entitled the Gold Mine Revitalization Act woula compensate. producers. Who sell gold in the United States, yet are not compensated for the difference in cost of production of th1s mineral in $1963 \mathrm{as}$ compared to the cost in 1940, the year the U.S.A. gold miners reached tyelr peak production. All components of gold production costs have increased to such an extent since 1940 that most gold miners have been forced to cease operations. The new bill would leave the price of gold at the pegged price of $\$ 35$ an ounce and authorlze conpensation for the increase in production costa over those of 1940. It 18 assumed that this legislation will not be opposed by the Treasury Department since it does not create a two price gold system and should not affect the value of the U.S. dollar.

There were 4,000 men employed in the gold mining Idustry in Alaska in 1940 compared to about 500 in 1962 .

\section{NESW MOLY DEPOSIT IN WYOMITF}

A major deposit of molybdenum ore has been discovered by Amerlcan Molybdenum Co. In the Brldger wilderness area of. Sublette County, Wyoming. Reserves are estimated at 24 mililion tons of ore containing more than $1 \%$ molybdenum. W1Iderness restrictions on mintag have been waived because of the atrateglc nature of the Plnd, the company cald. The mine alte 1 at an elevation of 11,000 feet. Dense forest and rugged terraln have kept mining operations from public notice. The company has been active in the area for the past two years.

\section{JAPANESE MTIERAL ACTIVIIY}

Azuma Kako Company has announced that China has expressed an Interest in tradipg 250 tons of Jeprese metallic chrome for 20,000 tons of Chlnese manganese ore. Japan currently is importing manganese from India, Phili1ppines, and Soutb Africa. The Japenese are also negotiating for 100,000 tons of Chinese coal.

A Japanese steel corpany is developlag $\mathrm{rich}$ iron are deposits in Pahang, Malaya. Nippon Mining Company and the Mitsui Company are developing copper deposits at Mala, south of Ifmg, Peru. They Intend to ship 700 tons of concentrates a month.

\section{NEW FUBLICATIONS}

U.S. Geological Survey Bulletin 1142-G, Geology of the Red Dev1l Quickativer Mine, Alaskar: by E. M. Mackevett, Ir. and H. C. Berg. The report updates earller geologic descriptions of the Red Devil mine and provides additional data on the size, shape, and structural control of the deposits.

\section{AFRIAL FHOTORRAPHY}

Senator Gruening, in response to a request Prom Governor Egan, states that he has. recelved from the U.S. Geological Survey en explanation for frequent delays experienced

$$
-4-
$$


by purchaers of aerlal photographs from the Survey. Delays in delivery reault at times rom the 111 m being on loen to another Federal agency and not readily available to fill rutaide orders. Sometimes the delay regults from the need for military clearance. On other occalons it is caused by large orders for reproductions. The Geological survey hes custody of nearly all of the aerlal fllm negatives of the acceptable mapping photography of Alsaka taken by Federal agencies. It is anticipated that Federaliy owned film not now in the Survey'a cuetody will soon be acquired, thereby enabling the survey to maintain a complete f1le of mappling photography of Alaska. Thus, in effect, there w111 soon extet a central library of aerial photo negatives of Aleska, and delays caused by the necesalty to refer orders or borrow film will be elininated.

E. AND M. J. METAL MARKET PRICES

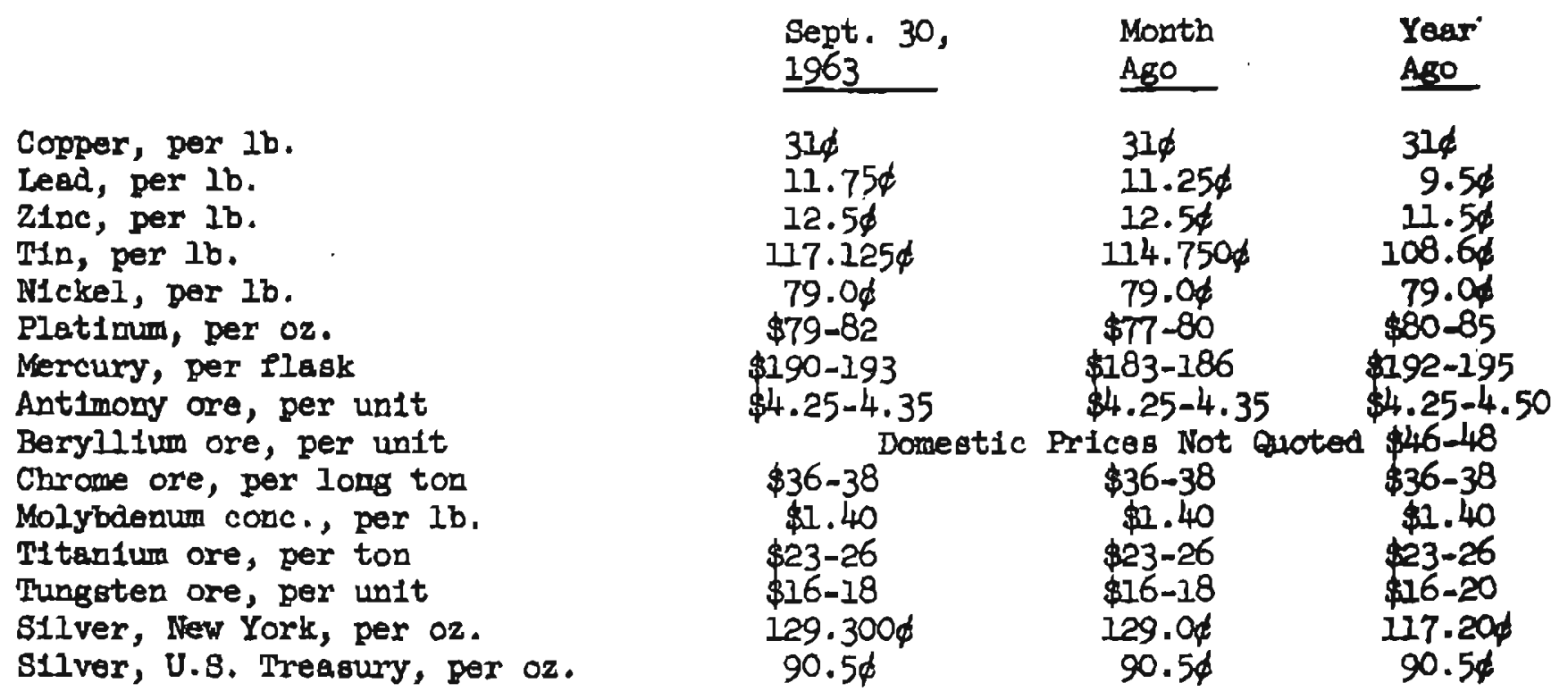



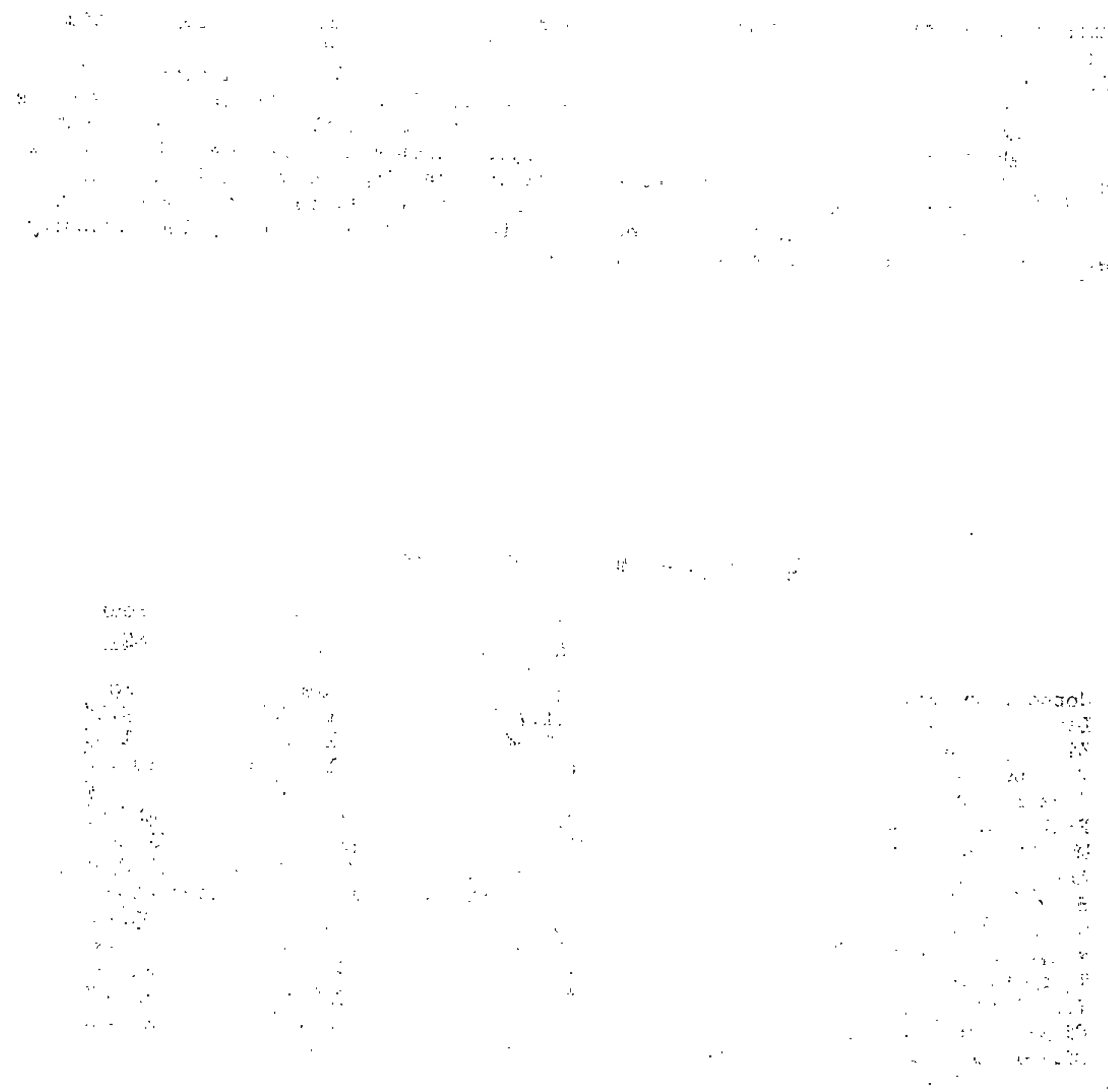